\title{
Study on ecological design of green space based on sponge city theory Yanyan Huang ${ }^{1, ~ a, ~ S i ~ B a i ~}{ }^{2, b}$ \\ 1Hubei University Of Technology, China \\ ${ }^{2}$ Hubei University Of Technology, China \\ A645187499@qq.com, b1124806545@qq.com,
}

\section{Keywords: Sponge city ; Park planning ; Ecological design.}

Abstract. With the rapid development of urbanization, the contradiction between human activities and ecological environment is becoming more and more serious, and the urban park green space is unable to meet the demands of people for the urban environment. Based on the theory of sponge city, the ecological design strategies of green space system of urban park are put forward, and then the ecological design ideas of urban green space system are analyzed in this paper. A good ecological system has been constructed to form a sustainable landscape effect and to promote the improvement of the ecological environment of green space in urban parks.

\section{Introduction}

The rapid development of urbanization aggravates the contradiction between human activities and ecological environment, and the urban park, with the function of recreation,leisure and entertainment, has been unable to meet the demands of the urban environment. It is a developing trend to construct development parks with ecological concept. The theory of "sponge city" is proposed. It is based on the ecological problems in cities in our country. Sponge city means the city can be like a sponge, which is flexible to adapt to environmental changes and to respond to natural disasters, and the proposition of "sponge city" theory provides a new train of thought and direction in the future urban development, which is an important chance to solve all kinds of urban ecological crisis.

\section{Overview of green Spaces in urban parks}

The green space of park is a land for afforestation, which is open to the public for recreation in the city as its main function, and in which their are some recreational facilities and service facilities, and which can protect the ecological environment and beautify the landscape and prevent and mitigate natural disasters .Urban park green space plays an active and indispensable role in alleviating the current urban environment problems and protecting urban ecology. It not only takes on the function of protecting and improving urban ecological environment, but also afforests and beautifies the urban environment to provide citizens a comfortable casual activity space. It is an important part of urban construction land,urban green land system and urban public facilities.

\section{Ecological design strategy of the green space system in urban park}

the arrangement of different elements about mountains,water,forests, fields and lakes

The treatment of water with mountain, the forests and fields will be combined to solve the problems about water resources, water environment, water ecology and water disaster. Afforestation, mountain protection and restoration are projected,and the maximization of the control rate of runoff is ensured , and the ecological priority is regarded as an important principle. The linkage effects between the green space in park and the water and canal are exploited,and various purification measures are applied.

Ensuring the storage capacity of "city sponge" 
Rivers, lakes and pond wetlands are natural rainwater purification site for city. They provide conditions for the construction of the riverside vegetation buffer zone, the riverside wetland, the rainwater retention pond and so on. The river back to nature reformation is implemented, and the straight river is transformed into curving, and then the retention time of floods in tributaries are extended., and the peak flood of main river is reduced..

Reasonable measurement of the carrying capacity of green spaces in park

The carrying capacity of green spaces in park is diverse, the thought that "the introduction of water is for water" should be discarded. Under the premise of meeting the ecological environment, landscape, recreation and other basic functions of green spaces, space conditions is set aside or created reasonably, the runoff of the green areas and surrounding hardened areas are permeated, regulated and purified, and the urban rainwater pipe system and the runoff discharge system of exceeded standard are connected.

\section{The ecological design of green space system base on sponge city theory}

The goal of the ecological design of green space system in urban park is to recycle rainwater, and to combine rainwater utilization with the overall planning and design of the park, and to reserve and utilize rainwater when the landscape of park is designed, so that the ecological benefits of green space are made full use of .Overall drainage plan for park is designed by utilizing terrain,water permeable pavement, rain garden, vegetation and other landscape elements, and the collection of rainwater is maximized. The collected rainwater is used to recharge the groundwater and construct the water landscape in the park.

The utilization of terrain

The design of slope, slope length and varying slope should be reasonable,in order to avoid the ground wash lead by rainstorm of the runoff. In order to meet the minimum requirement of the storage capacity of lakes in landscape in park,dredging, excavation, plastic surgery and other design work of the current water body are executed in the flat area of the park, and large number of silt will come into being.On the premise of the silt in park being not out of the park and the earthwork in the park being coordinating, the influence of slope and slope length on runoff should be taken into full consideration when landscape topography is piled up. The steeper the ground is, the faster the surface runoff runs, and the stronger the soil corrodes. The longer the slope is, the more the surface runoff come together,the stronger the power of the runoff scouring and eroding the soil is.

Organizing catchment

Catchment is organized by partitioning the park scientifically, and reasonable areas of catchment are ensured,and the wider runoff is avoided lest the soil may be scoured by it. A detailed survey of the terrain is conducted in the process of the vertical design of the park, and the functional subareas and the catchments section are delimited, and then the vertical design and the catchment scheme of each areas are planed uniformly with the surrounding areas and road elevation being combined. The effective interaction comes into being between catchment areas organized by partitioning the park and the primary waterscape areas, so that the rainwater is collected efficiently in the park.

\section{Collecting rainwater}

A series of management systems of rainwater harvesting are formed by constructing rainwater gardens ,dry creeks and stormwater wetlands , and the time of storm runoff gathering is extended, and the volume of runoff is decreased. According to the direction of rainwater catchment ,the catchment area and the estimation of the amount of rainfall in park, the number, location and area of rainwater garden is arranged reasonably.By designing terrain,rainwater comes together into the rain garden without having to go far, and then infiltrates into underground through the soil.If the amount of rainfall exceeds the infiltration capacity of soil, the rainwater will be discharged into stormwater wetlands 
(eatchment areas) through underground pipe or open ditch (dry creek).Based on actual land condition, the proportion of dry creek is enlarged suitably in capacious place, and the relative height difference is increased, and then the sedimentation basin is formed, so that the rainwater which comes from upstream can be subsided, and the amount of sediments brought from a long distance by rainwater are reduced, and the preliminary filter of rainwater is finished before the rainwater come into wetland. In the case of heavy rainfall, rainwater wetlands can collect rain and form a dynamic water landscape. All catchment areas are not treated with seepage control, and that the soil fully absorbs rainwater is allowed and then groundwater is supplied. The selective planting of rainwater wetland vegetation not only solves the problem of rainwater discharge and filtration, but also creates a beautiful landscape environment space.

material selection

The permeable pavement is used in road, square and parking.and then rainwater runoff is reduced and the resource of rainwater is collected. The roads in park can be classified into 4.5 8meter main roads, 3 meters landscape roads and other branches. The main roads in the park and landscape roads are paved with previous concrete, and the water permeable brick or permeable gravel are adopted in the branches, and all materials can guide rainwater to run through the surface to supply groundwater. The predicted previous concretes in the square is adopted, when ensured organization bearing, it can also pervious to water. The design of roads paving in the park are presented in Table 3.1 .

Table 3.1 Park road paving design

\begin{tabular}{|c|c|c|c|}
\hline $\begin{array}{l}\text { Road types } \\
\text { Design }\end{array}$ & Traffic rules & Width & Material \\
\hline $\begin{array}{l}\text { Tour ring road (main } \\
\text { route) }\end{array}$ & $\begin{array}{l}\text { Roads are mainly used for vehicle } \\
\text { walking,with sidewalks on both sides } \\
\text { of the road or either }\end{array}$ & $4.5 \sim 8 \mathrm{~m}$ & pervious concrete \\
\hline $\begin{array}{l}\text { Riverside landscape } \\
\text { road ( branch line ) }\end{array}$ & $\begin{array}{l}\text { The road is mainly for people.Small } \\
\text { garbage trucks can be allowed if } \\
\text { necessary. }\end{array}$ & $3 \mathrm{~m}$ & $\begin{array}{l}\text { water permeable } \\
\text { brick;permeable } \\
\text { gravel }\end{array}$ \\
\hline Walkway & $\begin{array}{l}\text { The road is mainly for people. Small } \\
\text { tour bus or bicycles can also be } \\
\text { allowed. }\end{array}$ & $1.0 \sim 3.0 \mathrm{~m}$ & $\begin{array}{l}\text { water permeable } \\
\text { brick;permeable } \\
\text { gravel }\end{array}$ \\
\hline
\end{tabular}

The assemblage of plants

Ground cover and shrub layer should be Cultivated actively, and multi-layer plant communities is constructed, and rainwater is absorbed at multiple levels, and the collection time of storm runoff is increased, and the surface runoff and soil erosion is reduced. Bare ground is easily eroded by rain, so plants is combined with the terrain to create abundant landscape effects and guide the flow of rain, and then the efficacy of ground runoff and irrigated vegetation are reduced during the wet season .Rainwater going through the slope full of plants slows down the impact of heavy rain on the ground and reduces soil erosion. At the same time, rainwater is intercepted by the vegetation and clears away contaminated particles effectively, and the organic species are left in the soil to provide nutrients for plants.

Plants are configured by means of selecting and collocating tree species, forming the multiple levers of ground cover, shrubs, small arbors, megaphanerophyte. Stereoscopic mixed plant communities break the monotony and formalistic hue of lawn, and the overall ecological benefits of green space are improved. Part of plants configuration in the park are presented in Table 3.2. 
Table 3.2 Part of plants configuration in the park

\begin{tabular}{|c|c|c|c|c|}
\hline Tree variety & The wetland area & Urban waterfront & $\begin{array}{l}\text { The area under the } \\
\text { shade }\end{array}$ & Open ground \\
\hline Cover plant & $\begin{array}{l}\text { reed;common } \\
\text { indian rice; } \\
\text { alisma }\end{array}$ & $\begin{array}{l}\text { pampasgrass; } \\
\text { cape jasmine; } \\
\text { multiflora; } \\
\text { rose; } \\
\text { rumex japonicus }\end{array}$ & $\begin{array}{l}\text { orychophragmus } \\
\text { violaceus; } \\
\text { short-tube lycoris; } \\
\text { shepherd's purse }\end{array}$ & $\begin{array}{l}\text { golden wave; } \\
\text { honeysuckle; } \\
\text { milk vetch; } \\
\text { astragalus smicus; } \\
\text { green bristlegrass; } \\
\text { coreopsis; } \\
\text { dandelion }\end{array}$ \\
\hline Bush & buckbean & $\begin{array}{l}\text { Chinese ash; } \\
\text { dryland willow; } \\
\text { hibiscus syriacus; } \\
\text { amorphafruticosa; } \\
\text { rosebay }\end{array}$ & $\begin{array}{l}\text { mahoniabealei } \\
\text { (Fort.)car; } \\
\text { cape jasmine; } \\
\text { primrose jasmine; } \\
\text { yucca gloriosa }\end{array}$ & $\begin{array}{l}\text { Chinese ilex; } \\
\text { common boxwood; } \\
\text { multiflora rose }\end{array}$ \\
\hline Dungarunga & $\begin{array}{l}\text { scirpus } \\
\text { tabernaemontani; } \\
\text { mosaic typha; } \\
\text { trollius } \\
\text { macropetalus }\end{array}$ & $\begin{array}{l}\text { Chinese pagoda tree; } \\
\text { Prunus cerasifera; } \\
\text { Yellow flag }\end{array}$ & - & $\begin{array}{l}\text { tequila; } \\
\text { mountain peach; } \\
\text { wild apricot }\end{array}$ \\
\hline Megaphanerophyte & $\begin{array}{l}\text { Cedar; } \\
\text { Metasequoia; } \\
\text { Maple; } \\
\text { slash pine }\end{array}$ & $\begin{array}{l}\text { salix babylonica; } \\
\text { alnus hirsuta }\end{array}$ & - & $\begin{array}{l}\text { podocarpus macrophyllus; } \\
\text { deodar; } \\
\text { white bark pine; } \\
\text { cedarwood; camphor tree }\end{array}$ \\
\hline
\end{tabular}

\section{Conclusions}

The concept of "sponge city" is still under development, and to create a "sponge city" theory and standard with Chinese characteristics has a long way to go, which needs to be explored in practice from various professional perspectives. Based on "sponge city" theory, and the ecological design tactics and design ideas of urban park green space system are put forward in this paper, and the study can be served as the references for urban park green space design.

\section{Acknowledgement}

This work is financially supported by the research on the planning and service of "The Three Gorges water township" in zhijiang city under the background of ecological civilization (Grant No.2016BLE115)

\section{References}

[1] Yu Zou, Yiqing Xu, Canhong Qiu The Research on Sponge City Construction in Southern Hilly Area-A Case Study of Ningxiang County in Hunan Province Economic Geography, 35 (2015), pp. 65-78 (in Chinese)

[2] Guohui Qu, Zhiqing ZhaoThe Connotation of the Digital Urban Planning and The Construction of A Sharing Platfor Journal Of HIT (Social Sciences Edition), 9 (2007), pp. 33-40(in Chinese)

[3] Weiwei Shao, Haixing Zhang, Jiahong Liu, Guiyu Yang, Xiangdong Chen, Zhiyong Yang, Hao Huang, Data Integration and its Application in the Sponge City Construction of CHINA, In Procedia Engineering, Volume 154, 2016, Pages 779-786, ISSN 1877-7058, 
[4] Xinhai LuThe Data Fusion and Integration Method of Multi-Source Urban Planning Geomatics and Spatial Information Technology, 28 (2005), pp. 47-49(in Chinese) 